\title{
Phenotypic analysis of alveolar macrophages in normal subjects and in patients with interstitial lung disease
}

\author{
DA CAMPBELL, LW POULTER, RM DU BOIS
}

From the Departments of Thoracic Medicine and Immunology, Royal Free Hospital School of Medicine, London

ABSTRACT Cytospin preparations of mononuclear inflammatory cells were made from bronchoalveolar lavage fluid obtained from 15 patients with interstitial lung disease (nine patients with sarcoidosis and six patients with cryptogenic fibrosing alveolitis) and six control subjects. These preparations were examined with a panel of monoclonal antibodies that have been shown to distinguish subpopulations of macrophage like cells in normal tissues. The lysosomal acid phosphatase activity of the cells was also assessed. Phenotypically distinct subpopulations of alveolar macrophages were identified in all samples studied. The results showed that all cell populations identified in bronchoalveolar lavage fluid from the groups with interstitital lung disease could be identified in the lavage fluid from normal volunteers. Some quantitative differences in the proportions of cells identified with particular reagents emerged. In each of the groups with interstitial lung disease increased proportions of cells were identified with RFD1 (interdigitating cell marker; $\mathrm{p}<0.01$ ) and in the cryptogenic fibrosing alveolitis group an increased proportion of alveolar macrophages was identified with RFD7 (tissue macrophage marker; $p<0.05$ ). The possibility that quantitative changes in alveolar macrophage subsets observed in the interstitial lung disease groups are relevant to the pathogenesis of these conditions is discussed.

Bronchoalveolar lavage is being used increasingly to obtain samples of inflammatory cells and to evaluate the function of these populations in interstitial lung disease. Alveolar macrophages are immunocompetent cells that may be central to the pathogenesis of interstitial lung diseases such as sarcoidosis and cryptogenic fibrosing alveolitis. ${ }^{1-3}$ It is clear, however, that the term alveolar macrophage may encompass a heterogeneous group of cells. ${ }^{4}$

Monoclonal antibodies are now available to probe the heterogeneity of the mononuclear phagocyte system $^{3-6}$ and along with immunocytochemical techniques ${ }^{78}$ can be applied to the cells obtained by bronchoalveolar lavage to determine the subpopulations of alveolar macrophages present. A phenotypic analysis of the alveolar macrophages in bronchoalveolar lavage can then be constructed with reference to the known patterns of reactivity of these monoclonal antibodies in normal tissues.

Address for reprint requests: Dr DA Campbell, Department of Thoracic Medicine, Royal Free Hospital, London NW3 2QG.

Accepted 6 December 1985
The aims of this study were (1) to determine which cell phenotypes exist among the population of alveolar macrophages in bronchoalveolar lavage fluid; (2) to determine whether there were qualitative or quantitative differences between the cell phenotypes identified in two groups of patients with interstitial lung disease and normal subjects; and (3) to attempt to relate these phenotypic changes to the immune responses occurring in the lung interstitium in these pathological processes.

\section{Methods}

\section{STUDY POPULATION}

Twenty one subjects were studied: 15 patients with interstitial lung disease (table 1) and six control subjects.

There were five men and four women aged 29-70 years with pulmonary sarcoidosis. The diagnosis was confirmed by the presence of non-caseating granulomas on transbronchial biopsy in each case, in the presence of an appropriate clinical picture and in the absence of other known causes of pulmonary granu- 
Table 1 Details of the patients

\begin{tabular}{|c|c|c|c|c|c|c|c|}
\hline \multirow{2}{*}{ Patient No } & \multirow[t]{2}{*}{ Age (y) } & \multirow[t]{2}{*}{ Sex } & \multirow[t]{2}{*}{ Radiograph* } & \multirow[t]{2}{*}{$A C E^{\dagger}$} & \multicolumn{3}{|c|}{$\%$ predicted } \\
\hline & & & & & $F E V_{1}$ & $F V C$ & $K C O$ \\
\hline \multicolumn{8}{|l|}{ Sarcoidosis } \\
\hline 1 & 39 & $\mathbf{M}$ & II & 146 & 69 & 64 & 42 \\
\hline 2 & 70 & $\mathbf{F}$ & III & 69 & 62 & 72 & NA \\
\hline 3 & 51 & $\mathbf{M}$ & III & 44 & 120 & 121 & 79 \\
\hline 4 & 45 & $F$ & II & 77 & 70 & 57 & 92 \\
\hline 5 & 29 & $\mathrm{M}$ & $\mathrm{O}$ & 79 & 105 & 106 & 60 \\
\hline 6 & 33 & $\mathbf{M}$ & II & 111 & 88 & 94 & 90 \\
\hline 7 & 34 & $\mathbf{F}$ & I & 32 & 79 & 79 & 100 \\
\hline 8 & 29 & $\mathbf{F}$ & III & 58 & 91 & 93 & 100 \\
\hline 9 & 33 & $\mathbf{M}$ & II & 74 & 78 & 80 & 100 \\
\hline \multirow{2}{*}{\multicolumn{8}{|c|}{ Cryptogenic fibrosing alveolitis }} \\
\hline 1 & 56 & $\mathbf{F}$ & D & NA & & & 78 \\
\hline 2 & 40 & $\mathbf{F}$ & D & NA & 71 & 66 & 100 \\
\hline 3 & 67 & $\mathbf{M}$ & $\mathrm{D}$ & NA & 82 & 77 & 52 \\
\hline 4 & 68 & $\mathbf{F}$ & D & $\mathbf{N A}$ & 68 & 80 & 94 \\
\hline 5 & 62 & $\mathbf{F}$ & $\mathrm{D}$ & NA & 75 & 80 & 70 \\
\hline 6 & 66 & $\mathbf{M}$ & D & NA & 58 & 71 & 100 \\
\hline
\end{tabular}

lomas. No patient was receiving medication at the time of bronchoscopy and all were non-smokers except for one, who smoked 15 cigarettes per day.

The diagnosis of cryptogenic fibrosing alveolitis was made in four men and two women aged 40-68 years; in four the diagnosis was confirmed at open lung biopsy and in the other two patients, who had coexistent connective tissue disease (scleroderma, rheumatoid arthritis), transbronchial lung biopsies were performed. No patient was receiving medication at the time of bronchoalveolar lavage and none had previously received corticosteroids; one was a smoker of 20 cigarettes a day.

The control group included three male volunteers (aged 29-41 years), and three patients (two male and one female, aged 32 to 70 years) who underwent fibreoptic bronchoscopy for the investigation of a single episode of haemoptysis (with a clear chest radiograph or an asymptomatic mass lesion on a chest radiograph; in the latter case lavage was performed on the lung opposite to the side of the lesion.
Two of the control group were smokers; none was receiving medication.

\section{BRONCHOALVEOLAR LAVAGE}

One hour after premedication with intramuscular $\overrightarrow{\vec{F}}$ papaveretum $10 \mathrm{mg}$ and atropine $0.6 \mathrm{mg}$ the upper 3 respiratory tract was anaesthetised with topical xylocaine $(4 \%)$. With the patient supine, a fibreoptic bronchoscope (model BFITR: Olympus Corporation) was passed via the nose. Either the right 0 lower lobe or the middle lobe bronchus was ana- $\tilde{x}$ esthetised with lignocaine (2\%) and the bronchoscope wedged in a lateral segmental bronchus.

A total of $180-240 \mathrm{ml}$ of sterile $0.9 \% \mathrm{NaCl}$, corrected to pH 7.4 with $8.4 \% \mathrm{NaHCO}_{3}$ and maintained at $37^{\circ} \mathrm{C}$, was introduced in $60 \mathrm{ml}$ aliquots and gently 윽 aspirated after each aliquot. The fluid was collected $D$ onto sterile siliconised glass maintained at $4^{\circ} \mathrm{C}$. In each case informed consent was obtained before the $N$ procedure and the approval of the hospital ethics committee was obtained before we started the study.

Table 2 Reactivity in normal tissues of reagents used

\begin{tabular}{|c|c|c|c|}
\hline Designation & Source & Type & Specificity \\
\hline $\begin{array}{l}\text { Monoclonal antibodies } \\
\text { RFDR1 } \\
\text { Leu M2 } \\
\text { RFD1 } \\
\text { RFD2 }\end{array}$ & $\begin{array}{l}\text { RFHSM } \\
\text { Becton Dickinson } \\
\text { RFHSM } \\
\text { RFHSM }\end{array}$ & $\begin{array}{l}\text { Mouse antihuman } \\
\text { Mouse antihuman } \\
\text { Mouse antihuman } \\
\text { Mouse antihuman }\end{array}$ & $\begin{array}{l}\text { Class II MHC antigen } \\
\text { Monocytes, macrophages } \\
\text { Interdigitating cells, small proportion B cells } \\
\text { Monocytes, macrophages, granulocytes, T } \\
\text { lymphocytes }\end{array}$ \\
\hline $\begin{array}{l}\text { RFD7 } \\
\text { Cytochemical reagent } \\
\text { Acid phosphatase }\end{array}$ & RFHSM & Mouse antihuman & Tissue macrophages \\
\hline
\end{tabular}


Table 3 Phenotypes of distinct macrophage like cells in normal human tissues

\begin{tabular}{|c|c|c|c|c|c|}
\hline \multirow[t]{2}{*}{ Source } & \multirow[t]{2}{*}{ Cell type } & \multicolumn{4}{|c|}{ Phenotype } \\
\hline & & $R F D I$ & $R F D 2$ & RFD7 & $A C P$ \\
\hline Tonsil tissue & Marginal sinus macrophage & - & + & + & + \\
\hline , & Tangible body macrophage & - & + & $+1-$ & + \\
\hline ", & Interdigitating cells & + & - & - & - \\
\hline Liver tissue & Kupffer cells & - & + & + & + \\
\hline Peripheral Blood & Monocytes & - & + & - & + \\
\hline
\end{tabular}

\section{PROCESSING OF LAVAGE FLUID}

The total cell count was determined from an aliquot of untreated lavage fluid in a modified Neubauer haemocytometer, and viability was assessed by cellular exclusion of trypan blue ( $>85 \%$ in each case). Mucus strands were aspirated from the lavage fluid. The lavage fluid was centrifuged at $450 \mathrm{~g}$ for five minutes and the supernatant decanted. After it had been washed twice in phosphate buffered saline $(\mathrm{pH} 7.2)$ the cell suspension was adjusted to a final cell count of $3 \times 10^{5} \mathrm{cells} / \mathrm{ml}$. Cytospin preparations obtained from aliquots of this suspension containing about 3 $\times 10^{4}$ cells were made in a Shandon Cytospin II (Shandon Instruments, Runcorn). After being air dried for one hour at room temperature the cytospin preparations were fixed in a chloroform: acetone mixture $(1: 1)$ for five minutes and then air dried before storage in plastic film at $-20^{\circ} \mathrm{C}$ until it was used. Differential cell counts were performed on a MayGrünwald-Giemsa stained cytospin preparation.

\section{IMMUNOCYTOLOGICAL AND HISTOCHEMICAL}

\section{ANALYSIS}

We have previously characterised the pattern of reactivity of a panel of monoclonal antibodies to cells in sections from normal tissues and cytospin preparations of peripheral blood monocytes (tables 2 and 3 ).

Cytospin preparations were incubated with this panel of monoclonal antibodies and immunocytochemical methods were used to determine cell phenotype. ${ }^{7}$ A standard method was used to detect acid phosphatase activity. ${ }^{8}$

In each case the studies were performed in duplicate, and 300 alveolar macrophage like cells in con- secutive high powered fields were assessed as either positive or negative (background staining only) for each reagent used. The percentage of alveolar macrophages identified in this manner was then recorded for each case and each reagent. Appropriate positive tissue controls (table 3 ) and reagent controls were used in each case to ensure quality and reproducibility of the immunocytochemical methods. In some studies combinations of immunocytochemistry and histochemistry were used, as described previously. ${ }^{8}$

\section{STATISTICAL ANALYSIS}

Statistical analysis was performed with the Wilcoxon rank sum test.

\section{Results}

TOTAL CELL YIELD AND DIFFERENTIAL

The total cell yield was four to six times higher in the patients with interstitial lung disease than in the control group (table 4). Differential cell counts showed a significantly greater lymphocyte count in the sarcoidosis group than in the control group $(p<0.01)$. The greater total cell yield implies also a greater yield of alveolar macrophages (up to a five fold increase) from the groups with interstitial lung disease than in the normal group.

\section{IMMUNOCYTOLOGICAL ANALYSIS}

Table 5 shows the percentages of alveolar macrophages identified in bronchoalveolar lavage fluid from normal subjects and the two groups of interstitial lung disease patients with each of the panel of monoclonal antibodies and the percentage of alveolar

Table 4 Total cell yields from bronchoalveolar lavage fluid and differential cell counts (means with standard deviations in parentheses)

\begin{tabular}{|c|c|c|c|c|c|}
\hline \multirow[t]{2}{*}{ Group } & \multirow{2}{*}{$\begin{array}{l}\text { Total cell yield } \\
\left(\times 10^{7}\right)\end{array}$} & \multicolumn{4}{|c|}{ Differential cell count (\%) } \\
\hline & & Lymphocytes & Macrophages & Neutrophils & Eosinophils \\
\hline \multirow{2}{*}{$\begin{array}{l}\text { Sarcoidosis }(n=9) \\
\text { Cryptogenic fibrosing } \\
\text { alveolitis }(n=6) \\
\text { Control }(n=6)\end{array}$} & $4.2(1.6)$ & $39.2(15.6)$ & $55.6(15.6)$ & $3.9(3.5)$ & $1.4(2.1)$ \\
\hline & $\begin{array}{l}6.1(5.6) \\
0.9(0.6)\end{array}$ & $\begin{array}{c}14.1(10.0) \\
6.8(6.7)\end{array}$ & $\begin{array}{l}70.1(15.3) \\
90.3(8.0)\end{array}$ & $\begin{array}{r}12.8(8.7) \\
2.6(2.8)\end{array}$ & $<1^{2.5(2.8)}$ \\
\hline
\end{tabular}


Table 5 Immunocytological and histochemical analysis of alveolar macrophages (mean percentages of alveolar macrophages identified with standard deviations in parentheses)

\begin{tabular}{|c|c|c|c|c|c|c|}
\hline \multirow[t]{2}{*}{ Group } & \multicolumn{6}{|c|}{ Monoclonal antibodies reacting with macrophages } \\
\hline & $A C P$ & $R F D R I$ & Leu $M 2$ & RFDI & RFD2 & RFD7 \\
\hline $\begin{array}{l}\text { Sarcoidosis }(n=9) \\
\text { Cryptogenic fibrosing alveolitis }(n=6) \\
\text { Control }(n=6)\end{array}$ & $\begin{array}{l}93(3) \\
91(6) \\
92(3)\end{array}$ & $\begin{array}{l}92(5) \\
85(12) \\
87(10)\end{array}$ & $\begin{array}{l}92(6) \\
81(14) \\
87(8)\end{array}$ & $\begin{array}{l}63(21) \\
63(8)^{*} \\
29(13)\end{array}$ & $\begin{array}{l}48(15) \\
55(14) \\
40(21)\end{array}$ & $\begin{array}{l}43(15) \\
57(15)^{* *} \\
32(14)\end{array}$ \\
\hline
\end{tabular}

$\left.\begin{array}{l}{ }^{*} p<0.01 \\ { }^{*} \mathrm{p}<0.05\end{array}\right\}$ by comparison with the control group (Wilcoxon rank sum test).

macrophages expressing cytochemical acid phosphatase activity.

About $90 \%$ of alveolar macrophages in each group studied expressed class II MHC antigens (HLA$\mathrm{DR} 1^{+}$). A similar percentage of positive cells was identified when the samples were analysed with LeuM2. There was no difference in lysosomal acid phosphatase activity between the three groups studied. Combination staining with ACP/RFDR 1 and $\mathrm{ACP} /$ LeuM2 indicated that some cells were $\mathrm{ACP}^{+}$, RFDR1 ${ }^{-}$and vice versa but most cells were ACP ${ }^{+}$, $\mathrm{RFDR}^{+}{ }^{+}$. A similar observation was made with ACP/LeuM2 combination staining (results not shown). The individual percentages of alveolar macrophages identified with RFD1, RFD2 and RFD7 in each of the three groups studied are shown in the figure. The proportion of alveolar macrophages identified with RFD1 (interdigitating cell marker)

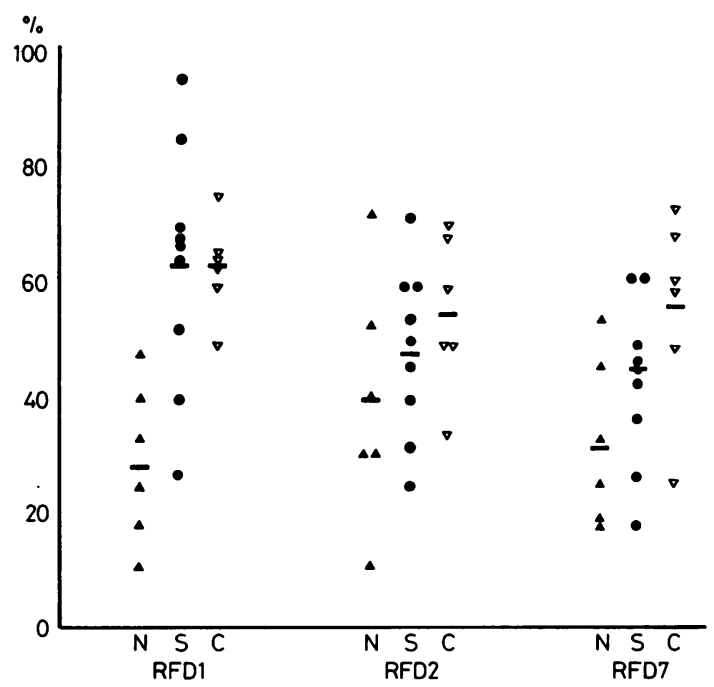

Percentage of alveolar macrophages identified with monoclonal antibodies RFD1, RFD2, and RFD7 for the individual patients and control subjects studied. The horizontal bars represent the mean for each group. RFDI-CFA and sarcoidosis v control: $p<0.01$; RFD7-CFA v control: $p<0.05 ; N$-normal control group; $S$-sarcoidosis group; $C$-cryptogenic fibrosing alveolitis. was significantly greater in both groups with interstitial lung disease than in the control group ( $p<$ 0.01). RFD7 (tissue macrophage marker) identified an increased proportion of alveolar macrophages in the group with cryptogenic fibrosing alveolitis $(p<$ 0.05 ). There was no difference in the proportions of alveolar macrophages identified with RFD2 (the monocyte-macrophage marker).

\section{PHENOTYPIC ANALYSIS}

The use of combinations of monoclonal antibodies and cytochemical methods showed that in normal bronchoalveolar lavage fluid the vast majority of alveolar macrophages are HLA-DR ${ }^{+}$and $\mathrm{ACP}^{+}$. Moreover, these methods showed most $\mathrm{RFD}^{+}$alveolar macrophage to be $\mathrm{ACP}^{+}$and a small proportion to be $\mathrm{RFDl}^{+}, \mathrm{ACP}^{-}$. From table 5 we see that in the groups with interstitial lung disease, where increased proportions of $\mathrm{RFDl}^{+}$and $\mathrm{RFD}^{+}$alveolar macrophages are found, the presence of an $\mathrm{RFD}^{+}$, RFD $7^{+}$phenotype can be predicted, and the vast majority of these are $\mathrm{ACP}^{+}$. In the interstitial lung disease groups the presence of an $\mathrm{RFDI}^{+}, \mathrm{RFD}^{+}$, $\mathrm{ACP}^{+}$phenotype can also be predicted. In normal tissues such phenotypes have not been detected; the presence of such phenotypes in normal bronchoalveolar lavage fluid cannot, however, be excluded.

\section{Discussion}

The evidence presented here shows that discrete cell phenotypes can be distinguished among alveolar macrophages obtained by bronchoalveolar lavage by immunocytological methods and that quantitative differences in the proportions of cells with particular phenotypes emerge in the interstitial lung diseases. A wide range of monoclonal antibodies reacting with cells of the monocyte-macrophage series has become available to probe the heterogeneity of the mononuclear phagocyte system. The specificity of these reagents varies from those restricted to circulating monocytes or tissue macrophages to those that have broad reactivity with monocytes and macrophages. $^{3-6}$ As with the lymphocyte this evident heterogeneity in the expression of membrane surface antigens perhaps reflects differences in functional 
capabilities within the mononuclear phagocyte system. ${ }^{9}$

Five monoclonal antibodies were used to identify subpopulations of alveolar macrophages in bronchoalveolar lavage fluid from normal subjects and two groups of patients with interstitital lung disease. The patterns of reactivity of these reagents have previously been characterised in a range of normal human tissues. ${ }^{5}$ The present findings confirm previous observations in showing that some monoclonal antibodies identify antigens shared by macrophages and interdigitating cells. ${ }^{510}$ The presence of increased numbers of RFD1 ${ }^{+}$alveolar macrophages in interstitial lung disease along with a 20 fold increase in numbers of $T$ lymphocytes in some patients may reflect immune mediated cellular interactions occurring in the pulmonary interstitium.

Studies in vitro have previously shown that alveolar macrophage accessory cell function differs from that of autologous peripheral blood monocytes, and that effector:target cell ratios determine the outcome of cellular interactions. ${ }^{1112}$ The RFD1 ${ }^{+}$population may define a subset of alveolar macrophages subserving the function of presenting antigen to $\mathrm{T}$ lymphocytes. Recent studies have found enhanced antigen induced proliferation of $\mathrm{T}$ lymphocytes mediated by alveolar macrophages in sarcoidosis, ${ }^{13}$ and we have previously provided evidence favouring the local induction of a humoral immune response in the lung in cryptogenic fibrosing alveolitis. ${ }^{14}$ The observation that a significant increase in the proportion of $\mathrm{RFD}^{+}$alveolar macrophages occurred in the patients with cryptogenic fibrosing alveolitis but not in those with sarcoidosis may reflect either local influences on alveolar macrophage maturation within the pulmonary interstitium in the two conditions or the wide range of disease activity in sarcoidosis itself.

The percentage of alveolar macrophages identified by the monoclonal antibodies RFDR1 and LeuM2 was similar in the controls and the groups with interstitial lung diseae, confirming a previous observation comparing patients with sarcoidosis and normal subjects. ${ }^{13}$ Using scanning and integrating microdensitometry, however, in conjunction with a mouse antihuman HLA-DR monoclonal antibody-glucose oxidase conjugate, we have been able to show that the mean density of HLA-DR antigen expression on the alveolar macrophages obtained by bronchoalveolar lavage from patients with pulmonary sarcoidosis is greater than that in control subjects (unpublished observations).

The presence of alveolar macrophages with the phenotype $\mathrm{RFD}^{+}, \mathrm{RFD}^{+}, \mathrm{ACP}^{+}$in bronchoalveolar lavage fluid in the groups with interstitial lung disease may be important since we have previously found this phenotype in lung biopsy speci- mens from patients with pulmonary sarcoidosis, ${ }^{5}$ and such a phenotype has not been observed in normal tissues so far examined. Peripheral blood monocytes $\left(\mathrm{RFD1}^{-}, \mathrm{RFD}^{+}, \mathrm{ACP}^{+}\right.$) have been observed to develop the $\mathrm{RFD1}^{+}, \mathrm{RFD}^{+}, \mathrm{ACP}^{+}$phenotype in conjunction with the physical changes of maturation when grown in tissue culture (unpublished observation). Could the presence of such a phenotype in lavage fluid represent a newly arrived population of monocytes maturing into alveolar macrophages in the lung? Such an observation would be in accordance with the data of Hance et al. ${ }^{3}$ These workers used monoclonal antibodies to identify monocyte lineage surface antigens and they were able to show that in bronchoalveolar lavage fluid from patients with sarcoidosis there was an increase in the proportion of alveolar macrophages identified with monoclonal antibodies that identify antigens preferentially expressed on peripheral blood monocytes - a finding that favours the concept of increased recruitment of immature macrophages to the site of disease activity.

We believe that the use of a panel of monoclonal antibodies that allow the immunocytological dissection of discrete subsets of alveolar macrophages will ultimately lead to the evaluation of the role of such subsets in the pathogenesis of the interstitial lung diseases. Functional studies of subpopulations of alveolar macrophages defined by monoclonal antibodies are currently being undertaken in this department.

DAC was the recipient of a grant from the North East Thames Regional Health Authority to RMduB. We express our gratitude to Ms Aida Condez for her excellent technical assistance.

\section{References}

1 du Bois RM. The alveolar macrophage. Thorax 1985; 40:321-7.

2 Danielle RP, Elias JA, Epstein PE, Rossman MD. Bronchoalveolar lavage: role in the pathogenesis, diagnosis and management of interstitial lung disease. Ann Intern Med 1985;102:93-108.

3 Hance AJ, Douches S, Winchester RJ, Ferrans VJ, Crystal RG. Characterization of mononuclear phagocyte subpopulations in the human lung by using monoclonal antibodies: changes in alveolar macrophage phenotype associated with pulmonary sarcoidosis. J Immunol 1985; 134:284-92.

4 Biondi A, Rossing TH, Bennett J, Todd RF. Surface membrane heterogeneity among human mononuclear phagocytes. J Immunol 1984;132:1237-43.

5 Campbell DA, Poulter LW, du Bois RM. Immunocompetent cells in bronchoalveolar lavage reflect the cell populations in transbronchial biopsies in pulmonary sarcoidosis. Am Rev Respir Dis 1985;132:1300-6.

6 Hancock WW, Zola H, Atkins RC. Antigenic hetero- 
geneity of human mononuclear phagocytes: immunohistological analysis using monoclonal antibodies. Blood 1983;62:1271-9.

7 Mason DY, Abdulaziz Z, Falini B, Stein H. Double immunoenzymatic labelling. In: Polak J, Van Noorden S, eds. Immunocytochemistry: practical applications in pathology and biology. Bristol: John Wright, 1983: 113-28.

8 Loyda Z, Gossrau R, Schiebler TH. Enzyme histochemistry. Berlin: Springer-Verlag, 1979:71-87.

9 Poulter LW, Janossy G. The involvement of dendritic cells in chronic inflammatory disease. Scand J Immunol 1985;21:401-7.

10 Radzun HJ, Parwaresch MR, Feller AC, Hansman ML. Monocyte/macrophage-specific monoclonal antibody $\mathrm{Ki}-\mathrm{M} 1$ recognizes interdigitating reticulum cells. $\mathrm{Am} \mathrm{J}$
Pathol 1981;117:441-50.

11 Liu MC, Proud D, Schleimer RP, Plant M. Human lung macrophages enhance and inhibit lymphocyte proliferation. J Immunol 1984;132:2895-903.

12 Ettensohn DB, Roberts NJ. Human alveolar macrophages support of lymphocyte responses to mitogens and antigens. Am Rev Respir Dis 1983;128:516-23.

13 Venet A, Hance AJ, Saltini C, Robinson BW, Crystal RG. Enhanced alveolar macrophage-mediated antigeninduced $\mathrm{T}$ lymphocyte proliferation in sarcoidosis. $J$ Clin Invest 1985;75:293-301.

14 Campbell DA, Poulter LW, du Bois RM, Janossy G. Immunohistological analysis of lung tissue from patients with cryptogenic fibrosing alveolitis suggesting local expression of immune hypersensitivity. Thorax 1985;40: 405-11. 